doi:10.7592/methis.v8i11.998

\title{
Nurklikud nullindad: sissejuhatuseks 21. sajandi esimese kümnendi kirjandusse
}

Piret Viires, Priit Kruus

Kultuuriteadusliku ajakirja Methis. Studia humaniora Estonica erinumber 21. sajandi esikümnendi ehk nullindate kirjandusest koondab kaheksa eesti kirjandusuurija uurimusi, millele lisandub teooriavahendus kahelt välisautorilt. Nullindate erinumbri algtõukeks oli 9.-10. detsembril 2010 toimunud kirjanduskonverents „Nurklikud nullindad“, mille korraldasid Eesti Kirjanike Liit ja Tallinna Ülikooli eesti keele ja kultuuri instituudi kirjandusteaduse osakond. Eesmärgiks oli süvendada mõttevahetust 21. sajandi esikümnendi eesti kirjanduse ja kriitika üle, olla omamoodi kokkuvõtteks aruteludele, mis olid toimunud nii ajakirjas Looming kui ka Nüpli kirjandusteaduse kevadkoolis 2.-3. juulil 2010. aastal. Konverents „Nurklikud nullindad" haaras kinni senistes käsitlustes esile tulnud nendingust, et nullindate eesti kirjanduses puudub korraga haaratav kuju ja kese; et on toimunud laialikasvamine ning seni äratuntaval ja korrapärasel kirjandusruumil on nullindatel palju erimõõtmelisi nurki.

Arutelu nullindate tähenduse üle algas 2000. aastate teisel poolel ja hoogustus kümnendi Iõpus. Diskussiooni nullindate üle eesti kirjanduses käivitas Tiit Hennoste artikliga „Piirideni jõudmine. Eesti kirjandus uuel sajandil“ 2006. aasta Loomingus (Hennoste 2006). Sellele järgnevalt avaldas 2009. aasta suvel Berk Vaher Sirbis artikli „Üle õue lendas linde: „nullindad" eesti kirjanduses" (Vaher, B. 2009). Ajakiri Looming algatas mõttevahetuse nullindate üle 2009. aasta septembris ja see kestis kuni 2010. aasta maini. Loomingu nullindate mõttevahetuses avaldasid arvamust Tiit Hennoste, Mart Velsker, Vaapo Vaher, Jan Kaus, Kalev Kesküla, Piret Viires, Aare Pilv, Märt Väljataga (vt Hennoste 2009, Velsker 2009, Vaher, V. 2009, Kaus 2009, Kesküla 2010, Viires 2010, Pilv 2010, Väljataga 2010). Kogu selle diskussiooniga oli kaudselt seotud Aare Pilve artikkel „Kirjanduslikest üheksakümnendatest ja Kajar Pruulist“ (Pilv 2009), kus üheksakümnendate taustal oli juttu ka nullindatest. Ja mõningaid üldistuslikke eeltakte pakkusid Märt Väljataga artikkel „Suure eesti romaani ootel“ (Väljataga 2007) ja Peeter Helme „Uuemad suunad Eesti kirjanduses 2005-2007“ (Helme 2007). Nendele kultuuriajakirjanduses ilmunud artiklitele järgnesid 2010. aastal juba mainitud Nüpli kevadkool (vt Nüpli 2010) ja konverents „Nurklikud nullindad“ (vt Nurklikud nullindad 2010).

Kui 1990. aastaid nähti suure murranguajastuna, siis nullindate määratlemisel oldi ebalevamad. Mitmed kriitikud leidsid, et nullindad jätkavad 1990. aastatel alguse saanud suundumusi, avaldati kahtlust ka kümnendipõhiste käsitluste otstarbekuse üle ja leiti, et nullindate tegeliku tähenduse mõistmiseks on vajalik settimisaeg ja ajalooline distants. 
Sellest hoolimata koorus nii mõttevahetusest, kriitikast kui ka konverentsiettekannetest välja teemadering, mis oma erineval kujul kordumises näitas, et tegemist on nullindatele omaste nähtustega. Nende hulgas on omaelulookirjanduse ja mälukirjanduse kasv, sellega seostuv piiride hägustumine faktuaalse ja fiktsionaalse vahel, reiskirjanduse pealetung, noore eestivene kirjanduse jõuline esiletõusmine, noorautorite ja eksperimentaalkirjanduse olulisus, uute tehnoloogiatega kaasnevad muutused, peale kirjanduse arengud ka teistes kultuuriliikides, näiteks teatris ja kunstis.

Siinse erinumbri koostamisel ongi püütud silme ees hoida neid nullindatele omaseid jõujooni. Nii ulatub nullindate kirjanduse teemadering siinses erinumbris digimodernismist postdraamani ja noorkirjandusest eesti venekeelse kirjanduseni, puudutades lisaks veel omaeluloolisust, reisikirjandust ja eksperimentaalkirjandust.

Nullindatel toimunud kirjandusaruteludes tõusis olulisele kohale postmodernismi lõppemise küsimus, millele keskendubki Piret Viirese avaartikkel „Digimodernistlik eesti kirjanik“, mis ühtlasi annab ülevaate valikutest, kuidas nimetada postmodernismile järgnevat (üksikud näiteid pikas võimaluste jadas: altermodernsus, neomodernism, kriitiline realism, uuslihtsus). Käsitledes eesti nüüdiskirjanduse ja uute digitaalsete tehnoloogiate suhteid, tõstatub artiklis küsimus eesti kirjanduse digimodernistlikust pöördest.

A a re Pilve käsitlus nullindate eksperimentaalkirjandusest keskendub samuti nimetamise probleemile - kuidas nimetada avangardseid tehnikaid kasutavat nüüdiskirjandust, mis küll eitab uuendamise ambitsiooni, aga on välja kujundanud uutest autoritest koosneva äratuntava tuumiku ja sisse töötanud mitmeid ilmumiskanaleid. Kindla piiritlemise ja nimetamise jätab Pilve artikkel „Väike teatmik (Tartu) paranoiakriitilise risoomi kohta“ tulevikukäsitluste hooleks, esitades sisutiheda kommenteeritud nimeloendi eksp-/Y-/miip-/paranoiakriitilise kirjanduse kohta.

Sarnaselt eelnevaga tutvustab ka Priit Kruusi artikkel "Nooruse valuuta. „Noorkirjanik“ ja „rühmitus“ nullindatel“ uusima kirjanduse terminoloogia kujunemist, ühtlasi käsitletakse siingi nüüdiskirjanduse kanaleid ja kogumikke, sealhulgas veebi kuuluvaid. Ka I gor Kotjuhi uurimus eesti venekeelsest kirjandusest keskendub nullindatel debüteerinutele, esitades põhjaliku käsitluse ühiskondlikest, poliitilistest ja kirjandusteoreetilistest vastuoludest, mis seni veel takistavad mõtestamast siinseid venekeelseid autoreid eesti kirjanduse iseenesestmõistetava osana. Samas on vaieldamatu, et nullindatel on venekeelsest eesti kirjandusest kujunenud aktiivne ja märgatav osa kodumaisest kirjanduspildist.

Autorite ja kanalite paljusus on nullindate jooksul muutnud arusaama kirjutamise ja kirjaniku tähendusest ja laiendanud teoste avaldamisvõimalusi nii veebis kui ka trükis. Nende protsessidega seonduvalt käsitleb Anneli Kõvamees artiklis "Nullindate reisikirjast: minu-vaated maailmale" reisikirjanduse plahvatuslikku menu nullindatel, täpsemalt kirjastuse Petrone Print „Minu...“-sarja. Nüüdisaegne reisikirjandus, mis keskendub subjektiivsetele 
elamuskirjeldustele, ei püüagi taotleda kõrgkunstilist taset ega panoraamset keskkonnakirjeldust, vaid keskendub oma mina uurimisele. Nimetatud tendentsi laiendavad ka teistele žanritele Leena Kurvet-Käosaar ja Rutt Hinrikus oma uurimuses „Omaelulookirjutus taasiseseisvumisest nullindateni“. Eesti kirjanduse kvantiteedi plahvatuslik kasv nullindatel on tugevalt seotud (oma)elulookirjutuse avaldumisvormidega (kuulsuste elulood, mälukirjandus, omaelulookirjutuslik luule, reisikirjandus jm). Ilukirjanduse ja faktikirjanduse segunemisega kaasnevad tôlgendamisraskused, kuna hägustuvaid piire on aina keerulisem märgata.

Piiride nihkumisest kõneleb ka Lu ule Epneri artikkel „Teispool draamat: tekst nullindate teatris“, mis annab ülevaate alusteksti, autorsuse ja lavastamisprotsessi muutumisest nüüdisteatris ja sellega seonduvatest uutest praktikatest (autoriteater, omadramaturgia, mitteverbaalsed teatrivahendid, ülekirjutamine).

Methise selle numbri teooriavahendus tuleb ringiga tagasi Piret Viirese artiklis tõstatatud küsimuse juurde, mis järgneb postmodernismile. Oma vastuse esitavad Timotheus Vermeulen ja Robin van den Akker, kes artiklis "Märkmeid metamodernismist" pakuvad välja, et postmodernismijärgset ajastut võiks analüüsida metamodernismi mõiste abil.

Tagantjärele vaadates olid nullindad ühiskondlikus plaanis murrangulisem aeg, kui kümnendilõpu diskussioonides kirjeldati. Toimus ju nullindate jooksul mitu ühiskondlikku vapustust, alates 2001. aasta terrorirünnakust, mis maailma tasakaalu tõsiselt mõjutas, kuni kümnendi lõpus levinud majandus- ja finantskriisideni. Üheks oluliseks nähtuseks kujunes nullindatel uute tehnoloogiate mõju ühiskondade toimimisele ja kodanikuühiskonna tugevnemisele. Vaieldamatult oli neil sündmustel otsene või kaudne mõju ka kultuurile. Nullindatel toimunud kultuurimuutusi on kõige põhjalikumalt käsitletud Aili Aarelaid-Tardi koostatud koguteoses „Nullindate kultuur" (Aarelaid-Tart 2012). Ühe märksõnana nullindate kultuuri kirjeldamisel näeb Aarelaid-Tart globaliseerumist ja seda, et eesti kultuuri võrdlusaluseks on saanud terve maailm. Samas tuleneb sellest ka mure rahvuskultuuri kestvuse pärast ja arutelu eesti kultuuri põhivoolude kompleksi üle (Aarelaid-Tart 2012: 8). Marju Lauristin on jõudnud aga järeldusele, et nullindatel on Eesti jõudnud siirdeühiskonnast võrguühiskonda (Lauristin 2012: 13).

Nii kerkibki nullindate kultuuri ja kirjanduse kohta üldistusi tehes üles küsimus ennekõike ajastust. 1990. aastate murrangulisus jõudis kultuuriprotsessides osalejateni vahetult ja teravalt. Nüüd, mõni aasta hiljem nullindatele tagasi vaadates tuleb tunnistada, et ka see periood osutus oluliste muudatuste ajastuks, ennekõike ühiskondlikus ja tehnoloogilises plaanis. Nullindate enda jooksul seda paraku niivõrd ei tajutud. Selles suhtes osutus õigeks arvamus, et nullindate tegeliku tähenduse mõistmiseks on vajalik settimisaeg ja ajalooline distants. 
Seega võiks praegune ajakirja Methis erinumber olla kokkuvõtlik käsitlus nullindate kohta, mida tulevikus koos teiste vastavateemaliste tekstidega analüüsida. Diskussioon nullindate üle algas 2006. aastal ja tinglikult võiksime lõpp-punktiks panna aasta 2013. Varsti jõuab kätte aeg, et hakata arutlema järgmise kümnendi - 2010. aastate üle.

\section{Ki r ja n d u s}

Aarelaid-Tart, Aili (koost) 2012. Nullindate kultuur I, II. Tartu: Tartu Ülikooli Kirjastus.

Helme, Peeter 2007. Uuemad suunad Eesti kirjanduses 2005-2007. - Sirp, 31. aug.

Hennoste, Tiit 2006. Piirideni jõudmine. Eesti kirjandus uuel sajandil. - Looming, nr 9, Ik 1395-1410.

Hennoste, Tiit 2009. Mälu ja elu. Grilliajastu kirjandus. - Looming, nr 9, Ik 1271-1280.

Kaus, Jan 2009. Liiga palju paljust. - Looming, nr 12, Ik 1687-1695.

Kesküla, Kalev 2010. Mälu impeerium, ajaloo eri. - Looming, nr 1, Ik 116-121.

Lauristin, Marju 2012. Eestlaste kultuurisuhte muutused liikumisel siirdeühiskonnast võrguühiskonda. - Nullindate kultuur I: teise laine tulemine. Koost. Aili Aarelaid-Tart. Tartu: Tartu Ülikooli Kirjastus, Ik 13-43.

Pilv, Aare 2009. „On lihtsalt niisugune nälg“. Kirjanduslikest üheksakümnendatest ja Kajar Pruulist. - Keel ja Kirjandus, nr 2, Ik 89-103.

Pilv, Aare 2010. Contra vulgatam. - Looming, nr 4, Ik 562-569.

Vaher, Berk 2009. Üle õue lendas linde: „nullindad“ eesti kirjanduses. - Sirp 19. juuni.

Vaher, Vaapo 2009. Etapp küll, kuid mitte epohh. - Looming, nr 11, Ik 1564-1573.

Velsker, Mart 2009. Uus kirjandus ja uued lugejad. - Looming, nr 10, Ik 1410-1425.

Viires, Piret 2010. Twilight Zone. Nullindad kui hämarala. - Looming, nr 2, Ik 273-282.

Väljataga, Märt 2007. Suure eesti romaani ootel. - Sirp, 31. aug.

Väljataga, Märt 2010. Oletusi ja kokkuvõtteid nullindate kirjandusest. - Looming, nr 5, Ik 713-725.

\section{Ve e b i a I l i k a d}

Nurklikud nullindad 2010. Nurklikud nullindad. Konverents eesti nüüdiskirjandusest. 9.-10. dets. Teesid. Tallinn: Tallinna Ülikool, Eesti Kirjanike Liit. - http://www.ekl.ee/pdf/Nurklikud_nullindad_ teesivihik_final.pdf (30.05.2013).

Nüpli 2010. XVII (XXV) kevadkool. O0ndate kirjandus ja kriitika: kas tõesti 0:0?. 2.-3. juuli. - http:// galerii.kirmus.ee/nypli/kevadkool/kevadkoolid/kevadkool-2010/ (30.05.2013). 